\title{
GRAIN LEGUMES GENETIC RESOURCES OF MEDITERRANEAN ORIGIN IN VIR COLLECTION: DIVERSITY AND USE IN BREEDING
} (review)

\author{
M.A. VISHNYAKOVA, T.G. ALEKSANDROVA, S.V. BULYNTSEV, \\ T.V. BURAVTSEVA, M.O. BURLYAEVA, G.P. EGOROVA, E.V. SEMENOVA, \\ I.V. SEFEROVA, I.I. YAN'KOV
}

\begin{abstract}
Federal Research Center the N.I. Vavilov All-Russian Institute of Plant Genetic Resources, Federal Agency of Scientific Organizations, 42-44, ul. Bol'shaya Morskaya, St. Petersburg, 190000 Russia, e-mail m.vishnyakova@vir.nw.ru, e.semenova@vir.nw.ru, t.alexandrova@vir.nw.ru, s.bulyntsev@vir.nw.ru, i.yankov@vir.nw.ru, t.buravtseva@vir.nw.ru, g.egorova@vir.nw.ru, i.seferova@vir.nw.ru,m.burlyaeva@vir.nw.ru

Received March 9, 2015

doi: 10.15389 /agrobiology.2016.1.31eng
\end{abstract}

\section{Abstract}

The introductions from the Mediterranean region to VIR collection of grain legumes genetic resources amounts $12 \%$ of its content. One-fifth of this sample accessions (1272) had been collected by N.I. Vavilov in 1926-1927, in his expedition around this richest floristic region. In the collection there are also large amounts of the accessions collected by P.M. Zhukovskyi, V.F. Dorofeev, K.Z. Boudin and other collectors from VIR. Many other accessions are obtained by the requests or as a result of exchange with breeding institutions of the countries situated around Mediterranean Sea and genebanks worldwide. The Mediterranean, a «hot spot» of the world's biodiversity, is one of the centers of origin of cultivated plants, including some economically important species of grain legumes. This is a region with many endemic species, both cultivated and wild relatives of legumes. In the countries of Mediterranean many species of legumes, including dry beans, cowpeas, vetch, white, yellow and blue lupines, chickpea, vetchling, lentil and grass pea had been domesticated. Common bean and soybean had been introduced and became an integral part of agricultural production in the region. All this makes the germplasm of the region very valuable. The article for the first time analyses the botanical and genetic diversity over 5500 samples of Mediterranean origin, introduced and stored in VIR collection and brief history of the process. In accordance with the N.I. Vavilov's rule of regularity in the geographical distribution of the traits, Mediterranean gene pool is phenotypically differentiated depending on the place of origin. The genotypes cultivated in the countries of western and northern Mediterranean for centuries been subjected to careful breeding, have been planted on fertile soils, in a mild climate and most of them are characterized by strong habit, large fruits and seeds. In the arid conditions of the southern and eastern parts of the Mediterranean basin early-maturated plants grow adapted to drought and heat (N.I. Vavilov, 1962). This Vavilov's discovery is the basis of the addressed assignment of the material from VIR collection for the regional breeding programs in accordance with ecological conditions and geographical position of the region. The paper for the first time provides the information about the features of the Mediterranean gene pool stored in the collection of grain legumes. The differentiation of the breeding status of the material is clear depending on the significance of the genus (species) or the crop in agricultural production in Mediterranean region. The collections of peas, soybeans, common beans from this gene pool are represented mostly by commercial varieties. The collections of lupine, cowpea, chickpea, beans, chicklings and vetch are comprised mostly of local varieties. Some genera (Vicia, Lathyrus, Lupin) are represented by numerous species of wild relatives. For all crops the examples of elite germplasm (sources of alleles of genes determining the valuable traits) for breeding identified in the collection of VIR as a result of its assessment are given. The examples of using of Mediterranean gene pool in breeding domestic and foreign varieties are also given.

Keywords: Mediterranean, plant genetic resources, grain legumes, endemic species, elite germplasm, valuable traits, breeding.

The Mediterranean Basin is a historical region, located on the shores of the Mediterranean Sea and uniting countries of Europe, Asia and Africa, as well as numerous islands and archipelagos. Severely rugged terrain and the variety of edaphoclimatic conditions led to a significant variability of the landscape and biological forms on this vast territory $\left(4\right.$ million $\mathrm{km}^{2}$ or, with the Southwest 
Asian highlands, more than 5 million $\mathrm{km}^{2}$ ) [1]. The region belongs to one of 34 biodiversity «hotspots» [2], thanks to the presence of 13,000 endemic species of vascular plants, or $4.3 \%$ of the global number of endemic species. In this the Mediterranean region is second only to Sundaland (South East Asia) and tropical Andes [3]. Endemic species make up $40 \%$ of the Mediterranean flora [4].

The Mediterranean basin is a region with the highest density of ancient civilizations in the Old World (Egyptians, Greeks, Romans, Phoenicians, Byzantines, Arabs, Franks, Ottomans), which enriched farming methods. The convenient location of the territory on the junction of the continents contributed to the rapid penetration and spread of cultivated plants [5]. It is not surprising that the Mediterranean region, with its «extraordinary concentration of species diversity» [6] and agronomy tradition, was one of the key research targets for N.I. Vavilov, P.M. Zhukovskii and, later, for other collectors from the All-Russian Research Institute of Plant Industry (VIR). The favourable climate, fertile soil and high culture of agriculture have made this region one of the main producers of crop products in the world.

The value of the Mediterranean gene pool is determined by a wide variety of traits, a long history of cultivation of many plants, the active breeding of traditional and introduced forms, which became widespread in the Mediterranean countries, and the presence of wild relatives of various species.

From ancient times, legumes are part of the Mediterranean ecosystem. In this region, the following species had been brought under cultivation and cultured for millennia: Pisum sativum L., Vicia faba L., V. sativa L., V. monantha Retz., V. narbonensis L., V. ervilia (L.) Willd., Lens culinaris Medik., Lathyrus sativus L., L. cicera L. [7]. According to J.R. Harlan [8], one third of the plant species that mankind has brought under cultivation for life sustenance grows here. Currently, legumes are widely used in the Mediterranean region for feed and food purposes. They are an integral part of the Mediterranean diet, contributing to high life expectancy in the countries of the region. Genetic erosion of the Mediterranean phytodiversity (in particular, the Mediterranean gene pool of cultivated leguminous plants and their wild relatives), which takes place here, as well as throughout the world, as a result of climatic, environmental, urban and other factors, makes its conservation an impelling need [9] and the concern of all the world's genebanks. The value of the seed material from the Mediterranean region is evidenced, for example, by the fact that among the Laureates of the «Man and the Biosphere» UNESCO Programme, as part of the International Year of Biodiversity (2010), was Salama El Fatehi (Morocco), the developer of the project «Evaluation of genetic resources of the endangered bean species ( $\mathrm{Vi}$ cia ervilia) on the territory of the Mediterranean Intercontinental Biosphere Reserve (Morocco-Andalusia, Spain)». Analysis of modern germplasm collections of Lathyrus L., Pisum L., Vicia L. and Lens Mill. revealed a representability of genetic resources from the countries having access to the Mediterranean Sea, as well as from the maximum concentration area, i.e. the Fertile Crescent in Turkey, Syria and Lebanon [10]. The paper clearly demonstrates the wealth of the region's species composition stored ex situ, and suggests the ways of its further conservation in situ.

This article is aimed at reviewing the diversity of cultivated plants and wild relatives of legumes from the Mediterranean region (regardless of the center of their origin) stored in the VIR's collection, and their use for domestic breeding.

History, composition and value of the Mediterranean gene pool of legumes from the VIR's collection. The Mediterranean center of plant diversity and domestication, with its four centers (Pyrenean, Apennine, Balkan and Syrian-Egyptian), is considered one of the largest in the world (Fig.). It is this region along with located in close proximity South-West 
Asian center covering three oases (Caucasian, Western Asian and North-Western Indian), which is associated with the origin of the major legumes (peas, lentils, vetch, vetchling, beans, lupine), and a number of forage legumes [11].

The mass accessions of legume

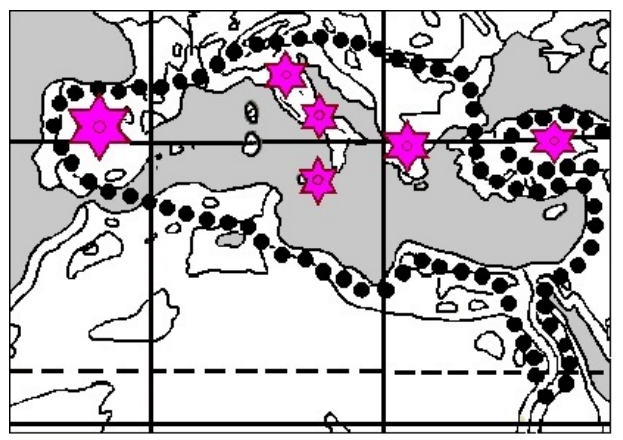

The Mediterranean center of origin and centers of diversity of cultivated plants [12]. specimens from the Mediterranean region have been established by the longest expedition of N.I. Vavilov (1926-1927), the route of which covered the territory of all the coastal countries and the largest islands, including Portugal, Abyssinia and Eritrea that have no direct access to the Mediterranean Sea. The number of leguminous specimens collected by N.I. Vavilov and his assistants M. Gaysinskii on Sardinia and R. Gudsoni in Egypt amounted to 1,262 [13]. Later, the collection was replenished due to expeditions of P.M. Zhukovskii to Syria, Turkey, Mesopotamia and other countries and island territories (1925, 1926, 1927, 1954), V.F. Dorofeev to Turkey (1967) and Syria (1974), K.Z. Boudin and V.L. Witkowskii to Algeria (1969), A.V. Pukhalskii and E.V. Mazhorov to Tunisia and Morocco (1970), etc. [14]. Over past two decades the accessions are mainly based on exchange with foreign researchers and genebanks.

Currently, the number of specimens from Mediterranean countries in the VIR's legume collection amounts to 5,563 (Table). Most legumes are known to have come from the South-West Asian center [11]. As floristic studies showed, there are 1,974 species of legumes [15] in the natural and cultural Mediterranean plants, which indicates the significant resource potential for the mobilization into the collection.

Specimens of leguminous crops and their wild relatives stored in the VIR's collection (N.I. Vavilov All-Russian Institute of Plant Genetic Resources; as of January 1, 2014)

\begin{tabular}{l|c|c|c|c}
\hline \multirow{2}{*}{ Genus, species } & \multirow{2}{*}{ Quantity, pcs } & \multicolumn{3}{c}{ From the Mediterranean region } \\
\cline { 3 - 5 } & & quantity, pcs & fraction, \% & countries represented \\
\hline Cicer arietinum L. & 3,310 & 779 & 23.5 & 15 \\
Glycine max (L.) Merr. & 7,267 & 286 & 4.0 & 8 \\
Lathyrus sp. & 2,066 & 367 & 17.8 & 11 \\
Lens culinaris Medik. & 3,040 & 606 & 19.9 & 13 \\
Lupinus sp. & 2,833 & 300 & 10.6 & 15 \\
Phaseolus sp. & 7,678 & 638 & 8.3 & 14 \\
Pisum sativum L. & 8,057 & 685 & 8.5 & 16 \\
Vicia faba L. & 1,964 & 231 & 11.8 & 17 \\
Vicia sp. & 5,509 & 1,499 & 27.2 & 11 \\
Vigna sp.: & & & & 11 \\
$\quad$ total & 4,068 & 92 & 2.2 & \\
$\quad$ incl. V. unguiculata (L.) Walp. & 1,847 & 80 & 4.3 & 12.0 \\
Total in the collection & 45,792 & 5,483 & \multicolumn{2}{c}{} \\
\hline
\end{tabular}

The natural features of the Mediterranean region, including flora, were found long time ago [16], but only the differential botanical and geographical approach, developed by N.I. Vavilov, revealed intraspecific variation of traits in the forms that grew in different parts of this vast territory, and their specific geographical location. For centuries, plants, handled in the countries of western and northern parts of the Mediterranean basin, have been subjected to careful selection, cultivated on fertile soils under conditions of mild climate, and most of them are characterized by a strong habitus, large fruits and seeds. Early ripening crops adapted to drought and heat are grown in the arid conditions of the south 
and eastern parts of the Mediterranean basin [11].

Geographically defined features, or «correctness of the intermutation process, which, upon closer examination, appeared to be a general process» [11], was demonstrated by N.I. Vavilov on a number of crops, including peas, beans, chickpeas and lentils. This discovery by N.I. Vavilov is the basis for addressed assignment of the source material from the VIR's collection for the regional breeding programmes in accordance with ecological and geographical conditions.

Very important gene pool is provided by wild relatives of cultivated plants, preserved in the region and carrying many valuable traits, the introgression of which into the cultigens may contribute to their agronomic improvement. For example, Spanish lupine (Lupinus hispanicus Boiss. et Reut.) growing in Spain and Portugal can serve as a donor of cold and drought hardiness, as well as disease resistance [17, 18]. Wild and local specimens of Turkish (Anatolian) vetches belonging to Vicia sativa possess many economically important traits needed for cultivation in northern conditions of our country [19].

Pe as Pisum L. Two species, $P$. sativum and P. fulvum Sibth. et Sm., are represented in the collection. Among 685 specimens of the Mediterranean origin, commercial and local varieties account for $46.0 \%$ and $38.0 \%$, respectively, and the wild forms and samples with unknown status make up $1.5 \%$ and $13.0 \%$, respectively. The primary centers of origin and diversity of peas, according to N.I. Vavilov [11], are mountain regions of the Western and Central Asia and Ethiopia, with the Mediterranean region being a secondary center. Recently, some of these views has been corrected, e.g. the primary center was allocated to the Western Asia (Iran, Afghanistan, Pakistan and Turkmenistan) and the entire Mediterranean region (Greece, Italy, Spain and Morocco), while Ethiopia was given the status of the secondary center [20]. In South-East Asia, due to low human influences, peas preserved many primitive features, while in Europe there was an intensive process of domestication [21] resulted in productive grain and vegetable forms. Here, they began to use recessive traits, which ultimately determined the breeding success. New morphotypes have appeared regulated by combinations or individual recessive alleles, such as leafless (af), semi-dwarf with shortened internodes (le, la, $l m$ ), with fasciated stem (fas, fa), etc. These plants are resistant to lodging, suitable for mechanized cultivation and harvesting. The combination of $h$ and $v$ alleles determines sweet peas. The $n n$ genotype results in minimum thickness of the bean pod halves. Good cooking characteristics in epep homozygote are due to maximum reduction of bean seed hypodermis [22].

Introgression of these and a number of other recessive alleles to cultivars has determined the phenotype and quality features of modern pea varieties. No wonder that the Mediterranean specimens include primarily commercial varieties. The major part of them (i.e., 268 varieties in the collection) came from France, one of the world leaders in the production of peas. Worldwide known French varieties often served as the initial material for the creation of our local varieties. Thus, the Baccara cultivar (k-8974), which dominated in commercial pea production in France for many years and was involved in pea breeding programmes in many countries, has been used at the All-Russian Research Institute for Legumes and Groat Crops (VNIIZBK, Orel Province); the early-maturing, productive and high-protein cultivar Supraduction Tezier (k-6025) is being involved in pea breeding at the Cheshminskaya Experimental Station. Quite active pea breeding has been undertaken in Spain, Italy, the former Yugoslavia, from where the VIR collection received 66, 39 and 44 samples, respectively. A large set of 125 samples from Turkey consists mainly of local varieties collected in expeditions by P.M. Zhukovskii (1926) and V.F. Dorofeef (1967).

The sources for valuable gene alleles, identified due to multi-year pea 
plant evaluations are k-2495 (Turkey), k-6018 (France), k-3108 (Italy), k-7262 (Algeria) (early ripening); k-2975 (Italy), k-3118, k-7573 (Spain), k-2593 (Cyprus), k-4421, (Yugoslavia), k-2415 (Algeria) (large-fruited); k-8577 (Spain) k8720, k-9263 (France) (leafless); k-5568, k-6017 (France), k-6151 (Morocco) (high seed productivity); k-2629 (Italy), k-6668 (France) (Fusarium-resistant); k6667 (France), k-2249 (Turkey) (Phomopsis-resistant); k-9342 (Greece) (resistance to black spot); k-7243, k-6936 (France), k-7644 (Algeria) (polycarpous, three and more beans per node) [23-25].

B road beans Vicia faba L. The primary center of its origin is the South-West Asia, while the Mediterranean region, where the large-seed forms are concentrated, is considered a secondary center. From here, beans penetrated into Europe and formed the locus of third significance, and there, following the impact of other environmental conditions, races with roughly podded fruit and straight and sturdy stems were isolated [26]. Modern research has showed that the domestication of beans and chickpeas could occur in north-western Syria, in close proximity to the Mediterranean coast in the X millennium BC [27].

All the variety of beans belongs to $V$. faba species. Among 231 samples of the Mediterranean origin, the local varieties account for $94 \%$, and those obtained as a result of scientific breeding make up only $6 \%$. In Europe, the diversity of local varieties of beans appears to be explained by long history of cultivation, as from ancient until relatively recent times they had mainly been the source of vegetable protein in food and feed. The import of soybeans, which began in the mid-twentieth century, has affected the production of beans and their breeding in Europe. However, in the Mediterranean countries they are still widely used in food and for animal feeding [28]. The bean breeding is developed in Spain and France, but as a food crop, they are more popular in North African countries [29].

The forms widely-spread in the Mediterranean countries are not of great variety, since large-seeded, light-coloured, medium- and late-maturing varieties dominate, with occasional medium-seeded forms. Small-seeded legumes are not grown everywhere, and they are even more uniform. A distinctive feature of Mediterranean beans is their thin pod valves and tendency to lodging. There are both early-maturing and late-maturing forms with a vegetation period of 94 to 132 days. Seed size, light coloration, pod shattering resistance, drought and cold hardiness, rust resistance, and high protein content are valuable features of the Mediterranean forms, however, a weak, subject to lodging stem is a disadvantage of these beans when mechanically harvested.

Long-term investigations of Mediterranean gene pool samples in the VIR experimental stations' network allowed to isolate valuable bean forms such as k1569, k-1571 (Egypt) (early ripening); k-1579, k-1581 (Sudan), k-1717, k-1832 (Italy), k-1577 (France) (high protein content in seeds); k-1575 (Syria), k-1582, k-1584 (Egypt), k-1416 (Yugoslavia), k-1470, k-1688 (France) (high seed productivity) [30].

Chickpea Cicer (Tourn.) L. The chickpea collection is represented by seven annual species, such as a cultivated species $C$. arietinum L. and wild C. bijugum K.H. Rech., C. cuneatum Hochst. ex Rich., C. echinospermum P.H. Davis, C. judaicum Boissier, C. pinnatifidum Jaubert et Spach, C. reticulatum Ladisinsky species, originated from the Mediterranean basin. Of these 779 samples, $90 \%$ are local varieties, $5 \%$ are cultivars resulted from scientific breeding, and $5 \%$ are wild species. The samples came from 15 countries, from the East (Iran, Syria, Turkey, Lebanon, Israel) to the West (Spain, France, Morocco) Mediterranean. According to M.G. Popov [31], the center of origin and distribution of species from the genus Cicer was located in the Ancient Mediter- 
ranean area, which started from the Atlantic Ocean shores and Morocco and, bordering both shores of the Mediterranean sea, stretched into Asia, including Asia Minor, Syria, Palestine, Mesopotamia, Persia, Transcaucasus, Turkmenistan, Uzbekistan and Afghanistan. E.N. Sinskaya [32] considers that the cultivted chickpea species $C$. arietinum is native to the Eastern Mediterranean (Asia Minor). In the coastal countries of the Mediterranean basin (Spain, Morocco, Algeria, Tunisia, Turkey, Syria, etc.), large-seeded varieties, most valuable for breeding, are distributed. The large-seed character in the significant part of them is combined with drought hardiness and relative resistance to Fusarium. Samples of chickpeas from Spain have good taste.

The sources of gene alleles regulating valuable traits of chickpeas from Mediterranean countries are k-277 (France), k-361 (Turkey), k-452 (Algeria), k626 (Palestine) (early ripening); k-278 (France), k-1886 (Spain) (high attachment of the lower bean); k-277 (France), k-340, k-343, k-608 (Turkey), k-125 (Palestine), k-453 (Algeria), k-798 (Italy) (large-seeded); k-355 (Turkey), k1943, k-1959, k-1972, k-1991 (Spain), k-2291 (Syria) (high seed productivity); k-278 (France), k-352 (Turkey), k-2648 (Syria) (compact habitus); k-1941, k1980, k-1981 (Spain) (high protein content in seeds) [33, 34].

Lentils Lens Mill. Based on hybridological and molecular genetic data, only two species are currently distinguished in the genus Lens, such as L. culinaris (cultivated) and L. nigricans (Bieb.) Webb et Berth. (wild) [35]. E.I. Barulina, the main monographist of the crop in the Soviet Union [36], divided the cultivated lentils $L$. sulinaris into two subspecies, macrosperma (Baumg.) Bar. (large-seeded, with large flowers and seeds of 7-9 mm diameter), and $\mathrm{mi}^{-}$ crosperma (Baumg.) Bar. (small-seeded, with small or medium-sized flowers and seeds of 3-6 mm diameter). The large-seeded plants are mainly used for breeding.

Among 606 Mediterranean samples, $5 \%$ are the varieties resulted from scientific breeding, the local varieties account for $70 \%$, and $25 \%$ possess unknown status. The origin of lentils is still debated. E.I. Barulina [37] believed that the cultivated species originated from the area between Afghanistan, India and Turkestan (between the Hindu Kush and the Himalayas), but now this area is considered a secondary center of lentils origin [38], as archaeological and molecular evidence indicate the border areas between Turkey and Syria, and between Syria and Jordan, as the center of domestication and the diversity of species $[39,40]$. The accessions from the center of maximum diversity are of particular interest. This is where most of the Mediterranean lentil specimens for the VIR collection were obtained from, namely 113 from Syria and 96 from Turkey, which are on top 10 of the crop producers. A total of 82 specimens came from Israel, and 65 and 61 from Morocco and Spain, respectively (western Mediterranean). Having spread along the shores of the Mediterranean Sea in the Neolithic Age, lentils became popular in many countries of the region.

The sources of valuable gene alleles are k-2722, k-2728 (Syria) (early ripening); k-538 (Turkey), k-1103 (Spain) (tall-growing); k-1084, k-1098 (Italy) (large-seeded); k-1045, k-585 (Turkey) (high protein content); k-1045 (Sicily), k-2727 (Syria) (high seed productivity); k-1829 (Yugoslavia), k-2222 (Italy) (resistance to Botritis cinerea Fr.). Using a k-538 specimen as the parent form, Rauza and Svetlaya cultivars have been developed in the VNIIZBK by crossings. These cultivars have high yield ( 2.84 to $3.05 \mathrm{t} / \mathrm{ha})$, a relatively large seeds with high (28.0 to $29.6 \%$ ) protein content, excellent product quality and cooking characteristics. During the observation period (2003-2010), they were not infected with diseases [41]. These cultivars suitable for all climatic zones of lentil cultivation in Russia contribute significantly to its increased production, though crop expansion is still limited due to unstable yields and poor suitability for 
mechanized harvesting. Involvement of the Mediterranean lentils with large seeds, high and slightly branching stem in the breeding programmes could help to obtain advanced cultivars.

Vetch Vicia L. Many species of the genus are endemics of the Ancient Mediterranean [42]. There are 58 representatives of species of the genus Vicia in the VIR collection, with more than a quarter of the specimens and more than half of the species diversity (1,499 samples of 39 species) being accessions from 17 countries of the Mediterranean region. The majority, being mostly wild forms and local varieties, are derived from Turkey, Syria, France, Morocco and Israel (343, 211, 167, 108 and 104 specimens, respectively). From Spain, which is recognized as the leader of vetch production in Europe [43], 209 samples were obtained. There are significant accessions of vetch from Italy, Algeria, Yugoslavia, Greece, Cyprus, Tunisia (91, 56, 55, 42, 44, 45 specimens, respectively), and other countries.

Common vetch ( $V$. sativa subsp. sativa) is an important forage crop in Russia. The species diversity center is located in the North-Eastern Mediterranean with the greatest concentration in the countries of the Fertile Crescent, i.e. Turkey, Lebanon, Syria, Iran, Iraq and the former Asian republics of the ex-USSR [44]. The collection contains 532 specimens of common vetch, including accessions from Spain, Israel, France, Turkey, Morocco, Syria, Italy, Greece, Algeria (145, 57, 60, 53, 40, 37, 27, 29, 16 specimens, respectivelt), Albania, Libya, Tunisia, Egypt, as well as about 300 specimens of closely related taxa, mainly $V$. sativa subsp. nigra (L.) Ehrh. and $V$. sativa subsp. cordata (Wulfen ex Hoppe) Arcang.

Geographical differentiation of the common vetch Mediterranean gene pool in accordance with the origin was clearly demonstrated via AFLP-profiling samples from two genebanks, the VIR and the Institute of Genetics of Plants (Leibniz-Institut für Pflanzengenetik und Kulturpflanzenforschung - IPK, Gatersleben, Germany) [45].

The sources of valuable gene alleles are k-920, k-923, k-33583 (Syria), k-965, k-1058, k-1062 (Turkey), k-102 (Italy) (early ripening); k1370 (Italy), k-34587 (Yugoslavia) (herbage productivity); k-1019 (Italy), k35043, k-36035 (Turkey), k-1141, k-35696, k-35915 (Spain) (seed productivity); k-1370, k-35167 (Italy), k-35761 (Spain) (high protein content in the herbage); k-34805 (Greece), k-35262 (France) (high protein content in seeds); k-1152 (Algeria) (drought hardiness) [46].

The samples of Mediterranean origin have been involved in breeding domestic vetch cultivars, e.g. k-33747 (France) for Orlovskaya 4 (VNIIZBK) and LOS-5 (Lgovskaya Experimental Breeding Station) cultivars, k-34456 (France) for Lugovskaya 85 cultivar (V.R. Williams All-Russian Fodder Research Institute, Moscow Breeding Station). The cultivars are listed in the State Register of Breeding Achievements admitted for use (2014) [47]. A Syrian specimen k33583 was involved in breeding Nemchinovskaya 84 cultivar (the Moscow Research Institute of Agriculture «Nemchinovka»), released in 1989.

The collection of bitter vetch $V$. ervilia (French lentils), the endemic species from the Mediterranean region, includes 334 specimens from the region, with 177 from Turkey, 57 from Spain, 31 from Israel, 27 from Cyprus island, and 15 from Syria. The initial bitter vetch domestication is believed to occur in the eastern Mediterranean region, i.e. Cyprus island, Syria, Palestine, Greece and, in part, Asia Minor, where the greatest diversity is shown. $V$. ervilia is characterized by drought hardiness and early maturity, it can mature even in the far north, with large herbage grown. This plant is mostly from mountainous countries [36].

Some sources of gene alleles in $V$. ervilia are k-161 (Turkey), k-339 (Cy- 
prus), k-384 (Spain), k-388 (Italy), k-439 (Greece), k-602 (Morocco) (drought hardiness); k-107, k-141 (Turkey), k-340, k-392 (Cyprus), k-281, k-295 (Israel), k-240, k-535 (Syria) (early maturity); k-253 (Syria), k-18 (France), k-112, k204, k-213 (Turkey), k-333, k-537 (Greece), k-390 (Spain), k-588 (Algeria) (seed productivity); k-213, k-259 (Turkey), k-356 (Italy), k-537 (Greece), k-588 (Algeria), k-230 (Tunisia) (productivity of herbage) [48].

Vetchling Lathyrus L. The Mediterranean region is the center of origin [11, 49] and diversity [50] of many vetchling species. The VIR collection possesses 56 species of Lathyrus, and 33 of them are of Mediterranean origin. The specimens are mostly wild species, and such as L. cicera, L. ochrus (L.) DC, L. tingitanus L., are cultivated ones. L. clymenum L., L. articulatus L., L. aphaca L., L. hirsutus L. are important only as forage and green manures, while L. odoratus L. (sweet pea) and L. sativus (grass pea) are mostly known and widespread in the horticulture and agriculture in different countries.

Among 367 specimens of vetchling of Mediterranean origin, $90 \%$ are local varieties, and $10 \%$ are wild forms. Specimens of grass pea first collected in 1926-1927 by N.I. Vavilov and P.M. Zhukovskii dominate in the collection. Currently, there are specimens from 11 Mediterranean countries, mostly from Greece, Italy, Algeria, Syria, Cyprus, France and Turkey. As to the number of species characteristic of these countries, the VIR collection is superior to other 15 world largest germplasm collections, and by the total number of specimens it is second only to the collection of the University of Pays and Adour (Université de Pau et des Pays de l'Adour, France) [51].

Grass pea was cultivated in Egypt and Asia Minor in 9500-7600 BC [52] and on the Balkan Peninsula in the early Neolithic Age at the beginning of the VI century BC [53]. Many local varieties have beneficial properties. Distinctive features of plants from the Mediterranean coast, including the Apennine and Iberian Peninsulas, the islands of Sardinia and Sicily, are high branching, fast growth, drought and cold hardiness, strong demand to heat during ripening, large seeds, white seed colour, productivity, high protein content in seed and hay, resistance to fungal diseases. Specimens from these territories were the source material for all large-seeded varieties obtained from scientific breeding in our country. Many forms and varieties from the Cyprus, Turkey, Egypt, the mountain regions of Algeria and Spain stand out for their early ripening (the vegetative season is 70 days) [54].

The sources of valuable gene alleles are k-775 (Spain), k-1114 (France), k-801, k-865, k-870 (Turkey) (early ripening); k-30, k-742, k-1112 (France), k791, k-879, k-880 (Italy), k-410 (Cyprus), k-884 (Spain) (high productivity); k390 (Cyprus), k-420 (Italy), k-1110 (France) (high productivity of seeds and herbage); k-774, k-775, k-778, k-781 (Spain), k-791, k-795 (Italy), k-1112 (France) (large-seeded); k-417 (Algeria), k-706, k-983 (Italy), k-1095, k-1363 (Turkey) (high protein content in seeds); k-773 (Spain) (high protein content in herbage); k-1221 (Yugoslavia), k-703, k-765, k-770, k-879, k-881 (Italy), k-774 (Spain), k-395, k-398, k-409, k-411 (Cyprus), k-30 (France) (Ascochyta resistance); k-406 (Cyprus), k-781 (Spain) (resistance to Erysiphe communis Grev r. lathyri Rabh.); k-836 (Yugoslavia), k-888 (island of Sardinia), resistant to rust pathogen Uromyces pisi (Pers.) Schröt [55-57].

Among other species of vetchling from the Mediterranean region, there have also been identified specimens with various valuable features, such as high protein content in seeds, k-200 (L. tingitanus) and k-135 (L. ochrus) (France); high protein content in herbage, k-387 (Cyprus), k-769 (L. cicera) (Italy); resistance to Ascochyta and rust, k-200 (L. tingitanus) and k-135 (L. ochrus) 
(France), k-443 (L. ochrus) (Turkey); resistance to Uromyces pisi (Pers.) Schröt., k-1391 (L. tingitanus) (France) [56, 57].

Lupine Lupinus L. The number of lupine species from the Mediterranean region as the center of origin is small compared to those from the New World, and among them, the great economic significance is attributed to blue lupine (L. angustifolius L.), yellow lupine (L. luteus L.), and white lupine ( $L$. albus L.). The first two are cultivated from the middle of the XIX century, while white lupine is an ancient plant [49]. The VIR collection includes 50 species of lupine. The Mediterranean region is the origin and formation center of nine of them, such as L. angustifolius, L. luteus, L. albus, L. cosentinii Guss., L. hispanicus, L. pilosus Murr., L. atlanticus Glads., L. digitatus Forsk. and L. micrantus Guss. (841, 800, 494, 25, 18, 15, 9, 6 and 5 samples, respectively). Most of the accessions are scientifically-bred cultivars from Australia, Belarus, Poland and Russia, and approximately 300 of them were obtained directly from Spain, Egypt, Greece, Morocco, Italy, Israel (87, 53, 28, 36, 22, 15 samples, respectively). None of these Mediterranean countries are considered major producers of the crop, but all of them are located in the centers of its diversity. Therefore, most of the specimens $(70 \%)$ are represented with local varieties, and the remaining $30 \%$ are wild forms.

Carriers of valuable alleles among L. albus are k-3154 (Egypt), k3293, k-3294 (Israel) (early ripening); k-3109 (Egypt), k-3115 (Greece), k3118 (Yugoslavia) (early ripening and productivity); k-507 (Egypt), k-682 (Yugoslavia), k-2864, k-2865 (Greece) (resistance to Fusarium); k-294, k295, k-298, k-302, k-306 (Palestine), k-1435 (Greece), k-502 (Egypt), k2299, k-2298 (Spain), k-313, k-1600, k-1601 (Italy) (high protein content); k-290, k-294, k-295, k-298, k-302 (Palestine), k-1649 (Yugoslavia), k-2297 (Spain) (high oil content) [58]. Among L. angustifolius the valuable traits are found in k-3093 (Morocco) (resistance to grey mould); k-91, k-371, k-372, k-373 (Algeria), k-169 (Italy), k-2868 (island of Corsica) (high productivity); k-288 (Palestine) (early ripening); k-3347 (Turkey), k-2666 (island of Crete), k-3345 (Greece) (drought hardiness); k-288 (Palestine), k-169 (Italy) (high oil content). Of L. luteus, the k-2072, k-2076, k-2081, k-3343 (Turkey) (high productivity and drought hardiness); k-3341 (Italy) (early ripening, productivity, resistance to virus diseases) were shown to be worthy [46].

The gene pool of the Mediterranean lupine, stored in the VIR collection, is widely used in different countries. With the involvement of Palestinian samples, the Kievskii Mutant cultivar of white lupine was created in the Ukrainian Institute of Agriculture (Kiev Province), which stands out by early ripeness and high productivity, and is grown almost all over the world. In Russia, for the blue lupine breeding, the Apendrilon specimen from Greece is used as a source of high productivity, drought hardiness and resistance to Fusarium. Resistance to Fusarium from Italian wild forms of yellow lupine was transferred to the Borluta cultivar, developed in Germany [46].

B eans Phaseolus L. Bean seeds were brought to Europe (primarily to the Mediterranean region, to Spain and Portugal) from Central and South America (center of origin and species formation) around 1500 [59], and, due to the variety of flower and seed morphology of the introduced plants, the been seed delivery occurred several times and from different parts of America [60].

The VIR collection comprises five species of the genus. A total of 635 specimens of $P$. vulgaris L. samples (kidney bean) and 3 specimens of $P$. lunatus L. (lima beans) were obtained from the Mediterranean countries. The latter one is a typical subtropical species, which is common and popular in the Mediterranean countries, but almost never used in Russia. According to the breeding status, the 
scientifically-bred varieties, local varieties and breeding material amount to $36.4 \%$, $7.2 \%$ and $8.3 \%$, respectively, and $48.1 \%$ have no defined status. The accessions were mostly obtained from France (331 specimens), where its scientific selection has been performed from the middle of the XIX century. A significant part of specimens (87, of which 52 are breeding lines) was from the former Yugoslavia, particularly Serbia where bean breeding is being conducted. Large accessions were obtained from Italy, Spain, and Turkey where the crop is popular.

Sources of valuable alleles of $P$. vulgaris are k-12031, k-12063, k-12150, k-13412, k-14673 (France), k-15279 (Greece) (early ripeness); k-11963, k-12037 (France), k-15121 (Italy), k-15347 (Turkey) (productivity); k-11977, k-11993, k12018, k-12052 (France), k-10312 (Italy), k-12321 (Morocco), k-12952 (Greece), k-15169, k-15171 (Turkey) (protein content more than $27 \%$ ); k-12027, k-13403, k-14672, k-14690, k-14694 (France) (low trypsin inhibitor activity) [61]; k-2279 (Italy), k-76, k-14910 (France), k-12682 (Turkey) (weak photoperiodic sensitivity) [62]; k-12034, k-12049, k-12138, k-13967 (France), k-14160 (Spain) (drought hardiness); k-11992, k-13534, k-14664 (France), k-13328 (Tunisia) (cold hardiness); k-11771, k-11959 (France) (resistance to common mosaic virus); k-13063, k-14665 (France) (resistance to a number of disease).

Cow pea Vigna unguiculata (L.) Walp. The primary center of origin of this ancient food and fodder plant is allocated by some researchers to East Africa [6, 49, 63], and by others, it is the central and southern parts of the African continent [64], from where cowpea reached the Mediterranean region. The long history of Vigna cultivation in the vast territory of the Mediterranean region, along with hybridization and mutations have led to many local varieties, and as a result, modern genetic diversity in the Mediterranean gene pool is broader than that of African and North American [64]. Among the Mediterranean specimens, there are plants with bushy and procumbent form, with small and large seeds (weight of 1,000 seeds amount to 50 to $280 \mathrm{~g}$ ). The majority of specimens are early ripening (68 to 90 days), with good productivity and high protein content in seeds, and resistance to viral diseases [65, 66]. The varieties are mainly for food purposes. Many specimens are superior to other forms in the herbage, and are used for fodder and as a green manure. In the Mediterranean region, cowpea is grown almost in all countries, but primarily as a garden plant. Production areas are in Croatia and Cyprus [43].

The VIR collection of $V$. unguiculata contains only 80 specimens of Mediterranean origin from 11 countries (Algeria, Egypt, Tunisia, Cyprus, Greece, Turkey, Spain, Italy, Syria, France, Israel). Many specimens are characterized by high parameters, such as k-247 (Turkey), k-481 (Italy), k-1226 (Egypt), k-304, k-1221 (Syria) (seed productivity); k-292 (Algeria) (herbage productivity); k-492, k-495, k-896, k-1226 (Egypt), k-309 (Cyprus) (early ripening); k-309 (Cyprus) (early ripeness and seed productivity); k-247 (Turkey), k-304 (Syria), k-307 (Tunisia), k-309 (Cyprus), k-478, k-481 (Italy), k-518, k-901 (Egypt) (large-seeded); k-292 (Algeria), k-190 (Italy), k-247 (Turkey) (high protein content in the seed) $[65,66]$.

Soybean Glycine max (L.) Merr. Soybean is native to East Asian center of origin, located on the territory of China, Korea and Japan [67]. With the development of contacts with the Southeast Asian countries, a multiple delivery of soybean seeds to Europe occurred, there were repeated attempts to cultivate the plant, and already in 1740, soybeans were grown in the Botanical Gardens in Paris (Jardin des plantes de Paris) [68, 69]. Since 1880, the seed breeding firm Vilmorin-Andrieux (France) has offered soybean seeds in its catalogue for gardeners and farmers [69]. However, low import prices retarded soybeans production in Europe for a long time. At present, soy is cultivated only on 
364.9 thous. ha in 28 countries of the European Union, the largest portion of which (153.0 thous. ha) are the areas in Italy. In North Africa, soy is not widely produced [43].

A total of 286 soybean specimens in the VIR collection are of Mediterranean origin. The bulk of the material was donated to the VIR from various research and breeding organizations, and includes varieties resulted from scientific breeding as well as breeding material. Not all the varieties in the VIR collection received from the Mediterranean region (especially in the first half of the XX century) were developed there (for example, a sample obtained by N.I. Vavilov from an Italian seed company Ingegnoli in 1926 was from Japan). Most Mediterranean accessions of those years contained no information about the primary origin. Only since 1949, the large-scale accessions from Mediterranean countries have begun, evidencing the development of breeding and production of soybeans in the region. Specimens were mostly received from France, Yugoslavia and Algeria (137, 85 and 47, respectively), and small sets came from Italy, Israel, Morocco and Syria.

Under the conditions of the Krasnodar Krai and the south of Ukraine the important traits were found in k-5935, k-8216 (Algeria), k-5529 (Israel), k10089, K-10091 (Italy), k-5895, k-5798 (France), k-9655, k-9931 (Yugoslavia) (high seed productivity); k-5724, k-5749, k-9470 (France), k-5317, k-8268 (Yugoslavia) (early ripening); k-5543, k-8268 (Yugoslavia), k-5865, k-6226 (France) (high protein content in seeds); k-10086 (Italy), k-9233, k-10148 (France), k-9653, k-9936 (Yugoslavia) (high oil content in the seed) [70-72].

Therefore, the recognition of the Mediterranean basin as one of the «hotspots» of global biodiversity, and the territory of the Fertile Crescent as the «hotspot» of species diversity of the major genera of legumes in the Old World (Lathyrus, Pisum, Vicia and Lens) indicates unconditional importance of the region to collect and save this plant genetic resources both in situ and ex situ (in germplasm collections). An example of the VIR collection, where the Mediterranean gene pool of legumes, depending on the crop, amounts from $3.1 \%$ to $23.8 \%$, demonstrates its diversity and value for breeding. The investigation of this gene pool is equally important for botany, ecology, geography, for phylogenetic analysis and understanding the cultivated plant evolution.

\section{REFEREN CES}

1. Bol'shaya Sovetskaya Entsiklopediya. Tom 24. Kniga 1 [Great Soviet Encyclopedia. V. 24. Book 1]. Moscow, 1976.

2. Mittermeier R.A., Robles G.P, Hoffmann M., Pilgrim J., Brooks T., Mit te rme ie r C.G., La moreux J., d a Fonseca G.A. Hotspots Revisited: Earth's Biologically Richest and Most Endangered Terrestrial Ecoregions. Washington, 2004.

3. Meyrs N., Mittermeier R.A., Mittermeier C.G., da Fonseca G.A.V., Ke nt J. Biodiversity hot-spots for conservation priorities. Nature, 2000, 403: 853-858.

4. $\mathrm{V} \mathrm{u} \mathrm{l'f} \mathrm{E.V.} \mathrm{Istoricheskaya} \mathrm{geografiya} \mathrm{rastenii.} \mathrm{Istoriya} \mathrm{flor} \mathrm{zemnogo} \mathrm{shara} \mathrm{[Historical} \mathrm{geography} \mathrm{of}$ plants. The history of floras of the globe]. Moscow-Leningrad, 1944.

5. Kli ma nova O.A. Materialy yubileinoi nauchnoi konferentsii «Kul'turnyi landshaft: teoriya $i$ praktika» [Proc. Conf. «Cultural landscape: theoretical and practical aspects]. Moscow, 2003: 42-44.

6. Vavilov N.I. Botaniko-geograficheskie osnovy selektsii (Uchenie ob iskhodnom materiale v selektsii). V kn.: Izbrannye trudy [In: Selected works. V. 2]. Tom 2. Moscow-Leningrad, 1962: 21-70.

7. Plant genetic resources of legumes in the Mediterranean. N. Maxted, S.J. Bennett (eds.). Kluwer Academic Publisher, 2001.

8. H a r l a n J.R. The living fields: our agricultural heritage. Cambridge University Press, 1995.

9. Neglected srops: 1492 from a different perspective (FAO Plant Production and Protection Series no. 26). Food and Agriculture Organization of the United Nations, Rome, 1994.

10. Maxted N., Hargreaves S., Kell S., Amri A., Street K., Shehadeh A., $\mathrm{Piggin}$ J., Ko no pk a J. Temperate forage and pulse legume genetic gap analysis. Bocconea, 2012, 24: 115-146 (doi: 10.7320/Bocc25.005).

11. V a vilov N.I. Tsentry proiskhozhdeniya kul'turnykh rastenii. V knige: Izbrannye trudy. Tom 5 [In: Selected works. V. 5]. Moscow-Leningrad, 1965: 9-107. 
12. Vavilov N.I. Selektsiya kak nauka.V knige: Izbrannye trudy. Tom 2 [In: Selected works. V. 2]. Moscow-Leningrad, 1960: 9-20.

13. V i s h n y a k v a M.A. Sel'skokhozyaistvennaya Biologiya [Agricultural Biology], 2012, 5: 31-38.

14. L o s k u to v I.G. Istoriya mirovoi kollektsii geneticheskikh resursov rastenii $v$ Rossii [History of world collection of plant genetic resources in Russia]. St. Petersburg, 2009.

15. Ri k li M. Das Pflanzenkleid der Mittelmeerländer. Bern, Hans Huber. 1943. Band 1.

16. G r a s s a ns k i i A.N. Priroda Sredizemnomor'ya [Nature of Mediterranean]. Moscow, 1971.

17. M a is u ry a n N.A., A t a b e k ov a A.I. Lyupin [Lupine]. Moscow, 1974.

18. V i s h n y a k o v a M.A. Sel'skokhozyaistvennaya Biologiya [Agricultural Biology], 2005, 2: 21-28.

19. Tu p i k ova A.Yu. V sbornike: Viki, boby i lyutserny Turtsii [In: Vetch, beans and alfalfa in Turkey]. Leningrad, 1932: 3-30.

20. S mýkal P., Kenicer G., Flavell A.J., Corander J., Kosterin O., Red den R.J., Ford R., Coyne C.J., Maxted N., A mb ros e M.J., E 11 is N.T.H. Phylogeny, phylogeography and genetic diversity of the Pisum genus. Plant Genetic Resources Characterization and Utilization, 2011, 9: 4-18 (doi: 10.1017/s147926211000033x).

21. M a k a s h v a R.Kh. Kul'turnaya flora SSSR. Tom 4. Zernovye bobovye. Chast' 1. Gorokh [Cultivated flora on the USSR. V. 4. Grain legumes. Part 1. Peas]. Leningrad, 1979.

22. M a k a h e va R.Kh. Gorokh [Peas]. Leningrad, 1973.

23. Makasheva R.Kh., Golubev A.A., Y a n'k ov I.I. Katalog mirovoi kollektsii VIR. Gorokh. Ustoichivost' obraztsov $k$ boleznyam $i$ vreditelyam. Vypusk 602 [Directory of the VIR World Collection. Peas. Resistance to diseases and pests. Issue 602]. Leningrad, 1991.

24. Rybnikova V.A., Rudikova A.A., Makasheva R.Kh., Serdyuk V.P., Yan ' ko v I.I. Katalog mirovoi kollektsii VIR. Novye obraztsy gorokha zernoukosnogo i ukosnogo ispol'zovaniya. Vypusk 646 [Directory of the VIR World Collection. New peas used for grain and mowing. Issue 646]. St. Petersburg, 1993.

25. S e rdyuk V.P., B e nken I.I., Z a morskay a Yu.M., Chmeleva Z.V., Nikish k i n a M.A. Katalog mirovoi kollektsii VIR. Gorokh (kharakteristika obraztsov po soderzhaniyu belka, antipitatel'nym veshchestvam $i$ drugim tsennym priznakam). Vypusk 727 [Directory of the VIR World Collection. Peas: protein content, decreased antinutritive compounds and other valuable traits. Issue 727]. St. Petersburg, 2000.

26. M u rat ov a V.S. Kul'turnaya flora SSSR. Tom 4. Boby [Cultivated flora on the USSR. V. 4. Beans]. Moscow-Leningrad, 1937: 75-124.

27. T a n n o K., Wi $11 \mathrm{cox}$ G. The origins of cultivation of Cicer arietinum L. and Vicia faba L.: early finds from Tell el-Kerkh, north-west Syria, late $10^{\text {th }}$ millennium b.p. Vegetation History and Archaeobotany, 2006, 15(3): 197-204 (doi: 10.1007/s00334-005-0027-5).

28. Duc G., Bao S., Baumc M., Redden B., Sadiki M., Suso M.J., Vishnia k ov a M., Z o ng X. Diversity maintenance and use of Vicia faba L. genetic resources. Field Crop Res., 2010, 115: 270-278.

29. S m a r t t J. Grain legumes: Evolution and genetic resources. Cambridge Univ. Press, NY, 1990.

30. De mina R.B., Miroshnichenko I.I., Matvienko L.N., Arkhipov V.S. Katalog mirovoi kollektsii VIR. Boby. Vypusk 107 [Directory of the VIR World Collection. Beans. Issue 107]. Leningrad, 1973.

31. P o p o v M.G. Trudy po prikladnoi botanike, genetike i selektsii, 1928-1929, 21: 3-240.

32. $\mathrm{S}$ i n s k a y a E.N. Istoricheskaya geografiya kul'turnoi flory [Historical geography of the cultivated flora]. Leningrad, 1969: 365-366.

33. Buly ntsev S.V., Tete r Z.Yu. Katalog mirovoi kollektsii VIR. Nut (ustoichivost' $k$ askokhitozu). Vypusk 697 [Directory of the VIR World Collection. Chick-peas (a resistance to askohitosis. Issue 697]. St. Petersburg, 1999.

34. Bulyntse v S.V., Gurki n a M.V., P e che rov A.A. Katalog mirovoi kollektsii VIR. Nut (iskhodnyi material dlya selektsii nuta v Astrakhanskoi oblasti). Vypusk 792 [Directory of the VIR World Collection. Chick-peas (original material for breeding in the Astrakhan' Province. Issue 792]. St. Petersburg, 2009.

35. Sh a r m a S.K., D aw s o n I.K., W a u g h R. Relationships among cultivated and wild lentils revealed by RAPD analysis. Theor. Appl. Genet., 1995, 91: 647-654.

36. B a ru li n a E.I. Chechevitsa SSSR $i$ drugikh stran [Lentils in the USSR and other contries] Leningrad, 1930.

37. B a ru li n a E.I. Chechevitsa. V knige: Kul'turnaya flora SSSR. Tom 4. Zernovye bobovye [In: Cultivated flora on the USSR. V. 4. Grain legumes]. Moscow-Leningrad, 1937: 127-167.

38. Ladizinsky G. The origin of lentil and its wild genepool. Euphytica, 1979, 28(1): 179-187 (doi: 10.1007/BF00029189).

39. Fratini R., Perez de la Vega M., Cubero J.I. Lentil origin and domestication. Grain Legumes, 2011, 56: 5-9.

40. Fergus o n M.E., Ford-Lloyd B.V., Robertson L.D., Maxted N., N e w bu ry H.J. Mapping the geographical distribution of genetic variation in the genus Lens for the enhanced conservation of plant genetic diversity. Mol. Ecol., 1998, 7: 1743-1755. 
41. Zotikov V.I., Golopyatov M.T., Borzenkova G.A., Vasil'chikov A.G., Glazova Z.I., Naumkina T.S., Rogozhkina A.I., Kondykov I.V., Gryadunova N.V., Varlakhov M.D., Varlakhova L.N., Novikov V.M., T S u kanova Z.R., Yanova A.A. Perspektivnaya tekhnologiya proizvodstva chechevitsy: metodicheskie rekomendatsii [An advanced technology of lentil production: guidelines]. Orel, 2011.

42. Kul'turnaya flora. Vika. Tom IV. Chast' 2 /Pod redaktsiei S.I. Rep'eva [Cultivated flora. Vetches. V. IV. Part 2. S.I. Rep'ev (ed.)]. St. Petersburg, 1999.

43. FAOSTAT, 2012 (http://faostat3.fao.org/faostat-gateway/go/to/download/Q/QC/E. Jan 7, 2013).

44. M a x t ed N. An ecogeographical study of Vicia subgenus Vicia. Systematic and ecogeographic studies on crop genepools. 8. Rome, 1995.

45. Potokina E., B lattner R., A lexandrova T., B a chman n K. AFLP diversity in the common vetch (Vicia sativa L.) on the world scale. Theor. Appl. Genet., 2002, 105: 58-67 (doi: 10.1007/s00122-002-0866-8).

46. Kurlovich B.S., Rep'ev S.I., Schcelko L.G., Budanova V.I., Petrova M.V., Buravtseva T.V., Stankevich A.K., Leokene L.V., Benken I.I., Rybnikova V.A., Kartuzova L.T., Zolotov S.V., Aleksandrova T.G., Debelyi G.A., Taranukho G.I., Teplyakova T.E., Malysh L.K. Genofond i selektsiya zernovykh bobovykh kul'tur (lyupin, vika, soya, fasol'). Teoreticheskie osnovy selektsii 3. Tom 3 [Gene pool and breeding grain legumes (lupine, vetch, soybean, kidney beans. Theoretical bases of breeding. V. 3]. St. Petersburg, 1995.

47. Gosudarstvennyi reestr selektsionnykh dostizhenii, dopushchennykh $k$ ispol'zovaniyu. Tom 1. Sorta rastenii [State Register of breeding achievements for use in the Russian Federation. V. 1. Plant varieties]. Moscow, 2014.

48. Voluzneva T.A., Kozhushko N.N., Volkova A.M., Andre eva N.N. Katalog mirovoi kollektsii VIR. CHechevitsa frantsuzskaya (otsenka zasukho- i zharoustoichivosti obraztsov). Vypusk 323 [Directory of the VIR World Collection. French lentils (estimation of drought and heat resistance). Issue 323]. Leningrad, 1981.

49. Z huk ovski i P.M. Kul'turnye rasteniya i ikh sorodichi. 2-e izdanie [Cultivated plants and their relatives. $2^{\text {nd }}$ edition]. Moscow, 1964.

50. Z e ve n A.C., De W e t J.M.J. Dictionary of cultivated plants and their regions of diversity. Wageningen, 1982.

51. Mathur P.N., Alercia A., Jain C., Aiss a A., Mc Inture A., Hag M., De 11 a A., Hanson J., Combes D., B a chmann K., Horvath L., P a t e 1 D.P., Dixit G.P., Sha rma R.N., Syouf M.Q., Nouh T.Z., Y ad av C.R., Bhat ti M.S., Burlyae v a M.O., C u a rd a C., R os a L., S i m o n C.J. Lathyrus germplasm collections directory. International Plant Genetic Resources Institute, Rome, Italy, 2005.

52. J a c k s o n M.T., Y u nu s A.G. Variation in the grass pea (Lathyrus sativus L.) and wild species. Euphytica, 1984, 33: 549-559.

53. K is le v M.E. Origins of the cultivation of Lathyrus sativus and L. cicera (Fabaceae). Econ. Bot., 1989, 43: 262-270.

54. Z a lk ind F.L. China [Grass pea]. Moscow-Leningrad, 1953.

55. S mirnova - I k o n n i kova M.I., G a r a n in a L.S. Byul. VIR, 1958, 4: 23-27.

56. K i r'y a n N.A. Otsenka iskhodnogo materiala dlya selektsii chiny na ustoichivost' $k$ gribnym zabolevaniyam. Kandidatskaya dissertatsiya [Estimation of original material used in grass pea breeding for resistance against pathogenic fungi. PhD Thesis]. Leningrad, 1973.

57. Burlyaeva M.O., Solov'eva A.E., Nikishkina M.A., Rasulova M.A., Z o l o t o v S.V. Zernobobovye i krupyanye kul'tury, 2012, 4: 62-71.

58. Chmeleva Z.V., B enken I.I., Kurlovich B.S., Naza rova N.S., Pilipenko S.I. Lyupin belyi (biokhimicheskaya kharakteristika obraztsov). Katalog mirovoi kollektsii VIR. Vypusk 496 [Directory of the VIR World Collection. White lupine: biochemical traits. Issue 496]. Leningrad, 1989.

59. Z e ve $\mathrm{n}$ A.C. The introduction of the common bean (Phaseolus vulgaris L.) into Western Europe and the phenotypic variation of dry beans collected in the Netherlands in 1946. Euphytica, 1997, 94: 319-328.

60. Papa R., Nanni L., S i c a rd D., R a u D., A t t e ne G. The evolution of genetic diversity in Phaseolus vulgaris L. In: Darwin's harvest: new approaches to the origins, evolution and conservation of crops. NY, 2006: 121-142.

61. B u ravts eva T.V., N i k is h k i n a M.A. Katalog mirovoi kollektsii VIR. Fasol'. Kharakteristika obraztsov po aktivnosti ingibitorov tripsina, soderzhaniyu belka $v$ semenakh $i$ drugim khozyaistvenno tsennym priznakam. Vypusk 745 [Directory of the VIR World Collection. Kidney bean trypsin inhibitors, seed protein content and other valuable traits. Issue 745]. St. Petersburg, 2004.

62. Ko s h k i n V.A., M t vi e n k o I.I., Eg o rova G.P. Katalog mirovoi kollektsii VIR. Fasol'. Kharakteristika obraztsov po fotoperiodicheskoi reaktsii. Vypusk 812 [Directory of the VIR World Collection. Kidney bean photoperiodism. Issue 812]. St. Petersburg, 2013.

63. I v a n o v N.R. Trudy po prikladnoi botanike, genetike i selektsii, 1937, 2: 41-106. 
64. Perrino P., Laghetti G., Zeuli P.L.S., Monti L.M. Diversification of cowpea in the Mediterranean and other centers of cultivation. Gen. Res. Crop Evol., 1993, 403: 21-132.

65. Pavlova A.M. Katalog mirovoi kollektsii VIR. Vigna. Vypusk 80 [Directory of the VIR World Collection. Cowpeas. Issue 80]. Leningrad, 1972.

66. Burlya eva M.O., Gurki na M.V., Ne krasov A.Yu., Ti k ho nova N.I. Katalog mirovoi kollektsii VIR. Vigna. Zernovye $i$ ovoshchnye obraztsy, perspektivnye dlya vozdelyvaniya $v$ yuzhnykh regionakh evropeiskoi chasti Rossiiskoi Federatsii. Vypusk 806 [Directory of the VIR World Collection. Cowpeas for grain and as a vegetable in southern part of he European Russia. Issue 806]. St. Petersburg, 2012.

67. Vavilov N.I. Uchenie o proiskhozhdenii kul'turnykh rastenii posle Darvina. V knige: Izbrannye trudy. Tom 5 [In: Selected works. V. 5]. Moscow-Leningrad, 1965: 157-176.

68. Pu e c h J. Les tentatives successives d'introduction du soja en France et leurs consequences. In: Soja. Paris, 1986: 9-13.

69. Shu rt le ff W., A o y a g i A. Early named soybean varieties in the United States and Canada (1890-2013): extensively annotated bibliography and sourcebook. Lafayette, 2013.

70. Korsakov N.I., To milin a T.B. Katalog mirovoi kollektsii VIR. Soya. Vypusk 292 [Directory of the VIR World Collection. Soybean. Issue 292]. Leningrad, 1980.

71. Sichkar' V.I., Lugovoi A.P., Ganzhelo O.I., Shchelko L.G. Katalog mirovoi kollektsii VIR. Soya. Iskhodnyi material dlya selektsii soi na yuge Ukrainy. Vypusk 555 [Directory of the VIR World Collection. Soybean. Original material for breeding in the southern Ukraine. Issue 555]. Leningrad, 1990.

72. S eferova I.V., N e krasov A.Yu., Sila eva O.I., K i y a s h ko N.I., Te t e r Z.Yu., K i va T.I., N i k i s h k i n a M.A. Katalog mirovoi kollektsii VIR. Soya. Iskhodnyi material dlya selektsii soi v Krasnodarskom krae. Vypusk 782 [Directory of the VIR World Collection. Soybean. Original material for breeding in Kasnodar Krai. Issue 782]. St. Petersburg, 2008. 